\title{
ERADICATION OF AL JAMAAH AL ISLAMIYAH IN INDONESIA
}

\author{
Bambang Waluyo, R. Narendra Jatna, Jamal Wiwoho \\ Task Executor of Vice General Prosecutor of The Republic of Indonesia \\ Email: bambang.waluyo127@gmail.com
}

\begin{abstract}
This article aimed at investigating the implementation of suppression and eradication of terrorism and its organizational existence in Indonesia for the sake of humanity. Apart from the less perfect Law of Terrorism Eradication and no Law specially governing terrorism funding responsively, the law enforcers have successfully used the existing legislations to make Indonesia obey the UN Security Council's Resolution Number 1267. The verdict against the cases of Zarkasih and Abu Dujana was the first verdict punishing the corporation in Indonesia, by stating that Al Jamaah Al Islamiyah is a forbidden corporation. It also proved the presence of terrorism funding for the first time. In addition, for the first time some assets were taken from Al Jamaah Al Islamiyah through fine of 10 million rupiahs imposed on JI's administrators, Zarkasih and Abu Dujana respectively. This case handling also proved that law is dependent not only on the legislations but also on the law enforcers themselves
\end{abstract}

Keywords: Terrorism Eradication, Corporation Funding, Al Jamaah Al Islamiyah

\section{A. INTRODUCTION}

Terrorism differs from violence (Thomas Santoso, 2002: 17); simply, violence can occur without terror, but terror cannot occur without violence. Terrorism is a set of coordinated attacks, which are aimed to generate terror feeling among a group of communities (HIS Jane's Intelligence Review, 2013). Terrorism is related to cause and effect in broad sense (Tore Bjorgo, 2015: 1). Different from war, terrorism action is not subjected to war procedure. For example, the implementation time is always sudden, and the target of life toll is random and civilians (Indriyanto Seno Adji, 2001: 17). Terror results in fear (Bambang Abimanyu, 2005: 62) and brings about terribleness, tremble, and shock (Louis Ma'luf, 1987: 282-283).

In Indonesia, terrorism has been becoming a global issue since the Bombing incidence on October 12, 2002 in Paddy's Pub and Sari Club in Legian Street, Kuta, Bali, followed with the final explosion occurring near the

1 Yustisia Vol. 6 No. 1 Januari-April 2017 Eradication Of Al Jamaah Al Islamiyah ....

(C) 2017; This is an Open Access Research distributed under the terms of the Creative Commons Attribution Licensee (https://creativecommons.org/licenses/by/4.0), which permits unrestricted use, distribution, and reproduction in any medium, provided the original work is properly cited. 
US's Consulate Office, constituting a horrifying terror. It was reported that there were 202 death tolls and 209 injured people. Most of them were foreign tourists who were visiting the location constituting the tourist destination. Indonesians were shocked with Bali bombing in 2002. It has never been imagined that there would be a very horrifying terrorism attack in Indonesian land (Institute of Defense and Strategic Studies (IDSS) \& Asia-Pacific Center for Security Studies (APCSS), 2006 : 4) (Kumar Ramakhrisna \& See Seng Tan, 2002 : 7). Bali Bombing is an organized terrorism action using style ala al Qaeda (International Crisis Group, 2002: 1). Those terrorists should be accountable for lawfully before the court.

In 2002, Indonesia had no law specifically governing terrorism crime. Terrorism handling before 2002 was conducted by using Law Number 11/PNPS/1963 regarding Subversion Activity Eradication (Anti-Subversion Law). The problem was that Anti-Subversion Law is domestic in nature so that it does not belong to cross-border crime, while terrorism crime has metamorphosed into international network or cross-border crime. Using subversion crime for Bali Bombing 2002 case, the handling of it would stop in the terror perpetrator individuals. It would be difficult to reveal the involvement of organization behind Bali bombing. Moreover, revealing the cross-border terrorist network was also difficult, whereas Bali bombing case was also supported with organization affiliated with Al Qaeda. More complicatedly, Anti-subversion Law has been withdrawn with the release of Law Number 26 of 1999 regarding Withdrawal of Law Number 11/PNPS/1963 concerning Subversion Activity Eradication, because it is considered no longer in line with Indonesia entering into reform era with democracy as the main jargon.

The emergency condition triggered with Bali bombing incidence led the Government to issue Government Regulation Substituting for Law (Perpu) Number 1 of 2002 on the Terrorism Crime Eradication. This Perpu was released following the Bali Bombing incidence in 2002. To enact it retroactively, Регри Number 2 of 2002 on the Enactment of Government

2 Yustisia Vol. 6 No. 1 Januari - April 2017 Eradication Of Al Jamaah Al Islamiyah .... 
Regulation Substituting for Republic of Indonesia's Law Number 1 of 2002 on the Terrorism Crime Eradication was released, in Bali Bombing Incidence in Bali on October 12, 2002, meaning that Pеrpu Number 1 of 2002 could not be used for Bali Bombing incidence in 2002. Just like the provision of Article 22, Paragraph (22) of State Constitution, Регpu should be approved by DPR (Legislative Assembly) in the following meeting; therefore both of Perpus (Numbers 1 and 2) were approved by DPR to be definitive Law on April 4, 2003 (the same), in which Perpu Number 1 of 2002 on the Terrorism Crime Eradication was amended into Law Number 15 of 2003 as the stipulation and Perpu Number 2 of 2002 on the Enactment of Perpu Number 1/2002 on the Terrorism Crime Eradication, in Bali Bombing incidence on October 12, 2002, into Law Number 16 of 2003. The trial of Bali bombing case began in 2003 against Imam Samudera and his colleagues. In such Bali Bombing trial, it could be seen the involvement of Al Jamaah Al Islamiyah affiliated with Al Qaeda led by Abu Bakar Baasyir.

Abu Bakar Baasyir was then trialed for his involvement in two incidences: Bali bombing and J.W. Marriot Hotel Bombing in Jakarta. Baasyir was imposed with terrorism crime for Bali bombing incidence. For Bali bombing incidence, he was not imposed with Terrorism crime. During this trial, there had been the Constitution Court's verdict through Constitution Court's Verdict Number 013/PUU-I/2003 stating that Law Number 16/2003 is in contradiction with RI's 1945 Constitution stating that such law does not bind legal power. It means that the application of Terrorism Crime law in Bali Bombing incidence is in contradiction with law. Baasyir, for his involvement in Bali Bombing, was imposed with the provision of Penal Code.

There is a consequence of Penal Code application to Bali Bombing incidence. Penal Code constituting the legislation product in early $20^{\text {th }}$ century, of course, cannot reveal the involvement of organized crime. Its criminal accountability stops in individual accountability as natuurlijke person. Using Penal Code, it is difficult to prove and to punish Al Jamaah Al Islamiyah mentioned as the terrorism organization in South East Asia, as the corporation. 
There is still an expectation to reveal the involvement of Al Jamaah Al Islamiyah in J.W. Marriot hotel bombing. For that reason, the interesting point is that amid regulation poverty in Indonesia, the public prosecutor should confront with the demand for proving the universal truth, the war against terrorism. Indonesia should have self-esteem before international world so that the existence of terrorism and its organizations in Indonesia should be suppressed and extinguished for the sake of humanity. How? This paper will address it.

\section{B. PROBLEM STATEMENT}

This article aimed to investigate how the implementation of suppression and eradication of terrorism and its organizational existence in Indonesia for the sake of humanity?

\section{RESEARCH METHODS}

This paper was the result of an empirical study of the author conducted as the public prosecutor in a quo case. The primary data were collected during the development of prosecution and during the trial in a quo case. To confirm the data, some Focus Group Discussions/FGDs were conducted with the participants consisting of public prosecutors, academicians, Islamic scholars, and Islamic activists. Meanwhile, secondary data were collected by studying journals, court verdicts, books, international resolutions and relevant law material references.

\section{RESEARCH RESULT AND DISCUSSION}

In the trial, the court has different perspective from the Public Prosecutor's in proving the involvement of Abu Bakar Baasyir in his capacity as the leader of Majelis Mujahidin Indonesia/MMI (Al Jamaah Al Islamiyah/JI) in Bali and J.W. Marriot bombing incidences that were declined by the Chamber of Judges. The judges of district court proved the involvement of Baasyir in Bali and J.W. Marriot bombing incidences, and the verdict of West Jakarta District Court was also as same as that of Provincial Court and 
Supreme Court's verdicts. However, the chamber of Judges for Judicial Review in the Supreme Court had different opinion, that there was no adequate evidence to punish Abu Bakar Baasyir, so that he was decided as not involved. Even he slipped away from the condemnation as the amir of MMI/JI.

There are some fundamental difference of evidence between Criminal Procedure Law (KUHAP) and Terrorism Criminal Law. The evidence in Criminal Procedural Law still uses a very simple approach, limited categorization. The evidence in Terrorism Criminal Law is broader including electronic evidence. In Baasyir trial, to prove his involvement in J.W. Marriot hotel bombing, the Public Prosecutor used broader evidence as governed in Terrorism Criminal Law. The judges, with different opinion, decided that Baasyir was evidently involved in Bali bombing incidence. The evidence was of course limited, as governed in the KUHAP. The effect of such different opinion can be seen in the verdict of judicial review. The evidence presented by public prosecutor is of course based on a broader Terrorism Crime Law, but as the Judge authenticated Bali bombing incidence using Penal Code, the evidence is more limited. Therefore, the Judicial Review's Chamber of Judges stated that the evidence was not sufficient.

$\mathrm{JI}$ is an Islamic radical group considered as a serious threat to the security in South East Asia, particularly Indonesia, related to the members of JI as the brains of Bali Bombing perpetrators and terrorisms' actions in Indonesia (Sukawarsini Djelantik, 2006: 2). Can Indonesia, therefore, prove and condemn Al Jamaah Al Islamiyah for its involvement in terrorism in Indonesia? Apart from legislation limitation, Al Jamaah Al Islamiyah has been stated as the forbidden organization factually and constitutionally and imposed with ten millions rupiah fine. How can the Indonesian law enforcers do this?

Robert Seidman (Robert E. Seidman, 1981: 60) suggests that:

"Lawyers, to some degree, have always played a problem solving role in society. In more developed communities, it sometimes appears that the principal technique in 'solving' emergent social problems is to operate an on-going, relatively stable system of law. In condition of 
underdevelopment, the lawyer frequently is more clearly engaged with the process of creating a new set of rules."

This quote reveals how the law enforcers make solution to Indonesian's obedience to the standard international provision, apart from its limited legislation on terrorism crime eradication. This approach is also in line with responsive law approach as mentioned in Law and Society in Transition by Philippe Nonet and Philip Selznick reviewed by Malcolm M. Feeley (Malcolm M. Feeley, 1979: 899) suggesting that:

"They posit three modes of legal order, repressive law, autonomous law, and responsive law. Each is distinguished from the other by purpose, method, and source of legitimacy. Repressive law appeals to the primitive need for order and social defense and relies heavily on coercion. Autonomous law emphasizes procedural regularity and predictability. Responsive law focuses on the substantive goals the community and views law as an instrument for achieving them."

This quote employs responsive law approach in which Indonesian law enforcers not merely take legal attempt to eradicate terrorism crime, without embedded rigidly into the legislative approach. Indonesian legal enforcers attempt to implement terrorism crime eradication not only from national legal perspective but also based on international law.

Chapter one will discuss Indonesia's obligations to implement the UN Security Council's Anti-Taliban Resolution. One of them is to impose sanction against the organization belonging to the list of terrorist individual and entity. Al Jamaah Al Islamiyah belongs to the list. The provision of limited legislation does not make Indonesian law enforcers submitted and embedded into the provision of legislation. The following chapter will discuss how Al Jamaah Al Islamiyah can be stated as a forbidden corporation and imposed with fine based on the court's verdict. This chapter will tell about the background of the selection of Abu Dujana and Zarkasih cases as the entrance to impose sanction against Al Jamaah Al Islamiyah. The last chapter will tell about how the law enforcers work using responsive law approach so that Indonesia will then complete its legislation with Terrorism Funding Prevention and Eradication Law. 


\section{UN Security Council's Anti-Taliban and Al Jamaah Al Islamiyah Resolution}

JI group uses salafy jihadi doctrine acquired through their members' experience in Afghanistan as the foundation of its movement. Through doctrines to do jihad with salafy madzhab and military science acquired in Afghanistan, the members of JI group were then motivated to commit a series of terrorism actions in Indonesia in 2000-2005. The UN Security Council's Resolution Number 1267 regarding Anti-Taliban mandates every state affiliated with UN to implement anti-terrorism activity. As the member of UN, Indonesia obligatorily implements this Resolution. In relation to the UN Security Council's Resolution Number 1267, there is a list of UN Security Council's sanction consolidation. The list contains the name of Jamaah Islamiyah (United Nation, 138). In detailed, the name of Al Jamaah Al Islamiyah is mentioned as follows.

QDe.092 Name: JEMAAH ISLAMIYAH
A.k.a.: a) Jema'ah Islamiyah b) Jemaah Islamiya c) Jemaah Islamiah
d) Jamaah Islamiyah e) Jama'ah Islamiyah F.k.a.: na Address: na Listed on: 25 Oct. 2002 (amended on 13 Dec. 2011) Other information: Operates in Southeast Asia, including Indonesia, Malaysia and the Philippines. Associated with the Abu Sayyaf Group (QDe.001). Review pursuant to Security Council resolution 1822 (2008) was concluded on 25 May 2010.

The mentioning of Jemaah Islamiyah name itself has resulted in a distinctive problem. Jemaah Islamiyah is a generic name. Jemaah Islamiyah can be defined as congregating Islam people. The appropriate name is Al Jamaah Al Islamiyah. The preposition $A l$ shows that the name is specific, in this case related to the name of organization. Therefore, the mentioning of Jemaah Islamiyah name results in an opinion that the UN 
Security Council's Resolution Number 1267 related to Al Jamaah Al Islamiyah is difficult to implement because of the inappropriate name existing in the list of UN Security Council's sanction consolidation. Referring to the verdict of Bali bombing cases, although the appropriate name is Al Jamaah Al Islamiyah, the abbreviation JI or Jamaah Islamiyah is understood as the organization affiliated with Al Qaeda. In this context, the name of Jemaah Islamiyah entity containing in Consolidation List is Al Jamaah Al Islamiyah. If JI is Al Jamaah Al Islamiyah, how coud Indonesia impose the UN Security Council's sanction on this entity?

$\mathrm{JI}$ is an underground organization. As an underground organization, is JI enlisted as an organization in Indonesia? Of course no, it is not. Indonesia has a legislation governing Societal Organization, Law Number 17 of 2013. When the UN Security Council's Anti-Taliban Resolution was released, Societal Organization was governed in Law Number 8 of 1985. A Societal organization can be sanctioned with organizational suspension or deprivation. But, how can JI suspended or deprived? As a clandestine organization operating underground, it must have never been registered or enlisted officially as the societal organization. Another problem arising is how Indonesia can execute the UN Security Council's Resolution Number 1267. Does the UN Security Council's Resolution Number 1267 mandate to condemn and to do confiscation against individuals and entities included into the list of UN Security Council's sanction consolidation, in this case, could JI be executed directly?

Indonesia holds on a monism principle. It is reflected in Law Number 24 of 2000. A new international provision can apply in Indonesia when Indonesia has ratified it in the form of Law. Similarly, the provision of Law Number 10 of 2004 regarding Legislation currently replaced with Law Number 12 of 2011 (UN Security Council's Resolution Number 1267 was released on October, 2004) presupposes the inclusion of Indonesian legislation for it to be enacted. Meanwhile the UN Security Council's 
Resolution is not an international agreement. As the members of UN, Indonesia obligatorily implements the UN Security Council's Resolution without necessarily ratifying it.

There is another factor making Indonesia not execute the UN Security Council's Resolution Number 1267 instantaneously. It is its order of implementation to confiscate the asset of individuals or entities, the name of which is included into the list of UN Security Council's sanction consolidation. Indonesia only recognizes criminal asset forfeiture and administrative asset forfeiture. In principle, Indonesia does not recognize civil asset forfeiture. Doing civil asset forfeiture, meaning non-conviction based forfeiture, is not recognized in principle. Asset forfeiture, moreover in relation to terrorism crime, should be done with conviction-based one. This condition inspires the Indonesian law enforcers. Indonesia can implement the UN Security Council's Resolution Number 1267.

\section{2. $\mathrm{JI}$ is a forbidden corporation}

The entrance to trace and to condemn JI is through Lajnah Ikhtiar Linasbil Amir (LILA) or the official commission of JI constituting the duty executor or caretaker of Al Jamaah Al Islamiyah. The condemnation of Abu Bakar Baasyir made JI losing its Amir or leader. For that reason, LILA was established as the Emergency Al Jamaah Al Islamiyah. During the trial against Abu Bakar Baasyir, the investigator and public prosecutor had no opportunity of sentencing the criminal sanction to Al Jamaah Al Islamiyah corporation. The position of Baasyir as the Amir of JI could actually be the foundation to condemn his organization as well. However the trial did not condemn Al Jamaah Al Islamiyah.

LILA provided an entrance to condemn JI as well. How could it be implemented? This opportunity was opened when Zarkasih alias Nuaim alias Mbaj alias Abu Irsyad alias Zahroni alias Roni alias Zainudin and Abu Dujana alias Ainul Bakri alias Mahmudi Yusro alias Mahfud alias Yusron alias Pak Guru alias Mas Ud alias Thorim alias Sobirin alias Dedi 
were arrested. During the arresting, it could be seen that Zarkasih was the Amir of LILA and Abu Dujana was the war commander of LILA. LILA and Al Jamaah Al Islamiyah were the same organization.

Considering this fact, law enforcers, investigators, and public prosecutor synergized to condemn the $\mathrm{Al}$ Jamaah $\mathrm{Al}$ Islamiyah corporation. The UN Security Council's Resolution Number 1267, particularly for forfeiting the asset of Al Jamaah Al Islamiyah, should be implemented through conviction-based principle in Indonesia. From the documentation in investigation and prosecution stage for Zarkasih and Abu Dujana, Article 9 in conjunction with Article 13 in conjunction with Article 15 in conjunction with Article 17 Paragraph (1) in conjunction with Article 17 Paragraph (2) of Terrorism Crime Eradication Law was imposed. The crime prosecuted in these articles includes illegal weapon and explosive substance ownership for terrorism purpose and helping and facilitating the terrorism perpetrators. How could Al Jamaah Al Islamiyah then be imposed with the sanction in the case trial?

Indonesia has no precedent to condemn corporation. It is not easy. Many parties should be convinced in investigation, prosecution and trial stages. Many of them did not understand that Indonesia should condemn Al Jamaah Al Islamiyah to implement the UN Security Council's Resolution Number 1267.

In Terrorism Crime Eradication Law, there is an opportunity of condemning corporation when the terrorism perpetrator is the corporation's administrators. Zarkasih and Abu Dujana were the administrators of Al Jamaah Al Islamiyah. Their position was a very important and strategic, as the Amir and War Commander. Terrorism crime committed by the administrators of corporation could condemn their corporation as well. Therefore the Terrorism crime committed by the Administrators of Al Jamaah Al Islamiyah could result in criminal sanction against the Al Jamaah Al Islamiyah. 
Al Jamaah Al Islamiyah is a Tandzim Sirri or clandestine organization. As a Tandzim Sirri, it is unlikely to be registered officially. So what sanction could be imposed on Al Jamaah Al Islamiyah? It was impossible to suspend or to deprive the license of Al Jamaah Al Islamiyah. For that reason, the most possible sanction was to declare it as the forbidden organization. In the prosecution of Zarkasih and Abu Dujana cases, the 15-year imprisonment was proposed for both of them and $\mathrm{Al}$ Jamaah Al Islamiyah was declared as a forbidden organization. To forfeit the asset of Al Jamaah Al Islamiyah, the two administrators of it, Zarkasih and Abu Dujana, were imposed with fine of 10 million rupiahs respectively.

Verdict issued by South Jakarta District Court Number 2189/Pid.B/2007 on April 21, 2008 against the defendant Abu Dujana contained fifteen-year imprisonment for the perpetrators, declaration of $\mathrm{Al}$ Jamaah Al Islamiyah as the forbidden organization, and imposition of fine of 10 million rupiahs. Then, Zarkasih was sentenced with the same punishment based on Verdict of South Jakarta District Court Number 2189/Pid.B/2007 on April 21, 2008.

This verdict was very phenomenal, as for the first time Indonesia condemned corporation. In addition, this verdict was the first one to cope with terrorism case and proved the aspect of terrorism funding, despite no Terrorism Funding Law at that time. How were Zarkasih and Abu Dujana cases related to terrorism funding?

The two defendants were condemned with Article 13 of Terrorism Crime Eradication Law. The article 13 states that every one deliberately helps or facilitates the terrorism crime perpetrators in the form of giving or lending money or other property. In the trial, it could be seen and proved that Zarkasih and Abu Dujana provided fund for military training for the terrorist in Philippines. For that reason, the two perpetrators as the administrators of Al Jamaah Al Islamiyah were also imposed with fine of 10 million Rupiahs. This case handling was also recorded in Digest of 
Digest of Terrorism published by United Nations Office on Drugs and Crime (United Nations Office on Drugs and Crime (UNODC), 2010: 8).

\section{E. CLOSING}

Investigators and Public prosecutors have synergized well. Apart from the less perfect Law of Terrorism Eradication and no Law specially governing terrorism funding responsively, the law enforcers have successfully used the existing legislations to make Indonesia obey the UN Security Council's Resolution Number 1267. The verdict against Zarkasih and Abu Dujana cases was the first verdict condemning the corporation in Indonesia, by declaring that Al Jamaah Al Islamiyah is the forbidden corporation. It also proved the presence of terrorism funding for the first time. In addition, for the first time some assets were taken from Al Jamaah Al Islamiyah through fine of 10 million rupiahs imposed on JI's administrators, Zarkasih and Abu Dujana respectively. In addition, this case handling also proved what Robert E. Siedman said that law is dependent not only on the legislation but also on the law enforcers themselves

\section{BIBLIOGRAPY :}

Bambang Abimanyu, 2005, Teror Bom di Indonesia (Bomb Terror In Indonesia), Jakarta: Grafindo.

HIS Jane's Intellegence Review, 2013, A head of the pack-Lone wolf terrorist attack increase, 19 July 2013

Indriyanto Seno Adji, 2001, Terorisme dan HAM dalam Terorisme: Tragedi Umat Manusia (Terrorism and Human Rights in Terrorism), Jakarta: O.C. Kaligis \& Associates.

Institute of Defence and Strategic Studies (IDSS) \& Asia-Pacific Center for Security Studies (APCSS), 2006, "Security Cooperation and Governance in Southeast Asia: Responding to Terrorism, Insurgency and Separatist Violence in Indonesia, Thailand and the Philippines," Conference Report, Singapore 
International Crisis Group, 2002, "Indonesia Backgrounder: How the Jemaah Islamiyah Terrorist Network Operates," Asia Report Number 43, Jakarta/Brussels: International Crisis Group

Kumar Ramakhrisna \& See Seng Tan, 2002, After Bali: The Threat of Terrorism in Southeast Asia, Singapore: World Scientific/IDSS.

Louis Ma'luf, 1987, Qamus al-Munjid fi al-Lugha wa al-a'lam, Kairo: Dar alKastulikiyyah.

Malcolm M. Feeley, Law Legitimacy and Symbols: An Expanded View of Law and Society in Transition, Book Review, Berkeley Law Scholarship Repository, Jan-Mar 1979.

Sukawarsini Djelantik, 2006, "Terrorism in Indonesia: The Emergence of West Javanese Terrorists." International Graduate Student Conference Series, Number 22, East-West Center

Thomas Santoso, 2002, Teori-teori Kekerasan (Violent Theories), Jakarta Ghalia: Indonesia.

Tore Bjorgo (ed.), 2005, Root Causes of Terrorism: Myths, Reality, and Ways Forward, London and New York: Routledge.

\section{Journal:}

Robert E. Seidman, 1981, Law and Development: The Interface Between Policy and Implementation, Boston College Third World Law Journal, Volume 2, Issue 1 Article 6.

\section{Internet:}

United Nations, Consolidated United Nations Security Council Sanctions List, New York, https://scsanctions.un.org/fop/fop?xml=htdocs/resources/xml/en/consolid ed.xml\&xslt=htdocs/resources/xsl/en/consolidated.xsl.

United Nations Office on Drugs and Crime, 2010, Digest of Terrorist Case, United Nations, New York, https://www.unodc.org/documents/terrorism/Publications/Digest_of_Terro rist_Cases/English.pdf. 